Gdańsk

\title{
Rodzina wobec śmierci dziecka. Żałoba, kryzys, wsparcie społeczne
}

Śmierć członka rodziny odbierana jest zazwyczaj jako doświadczenie bolesne. Ból nasila się, kiedy mamy do czynienia ze stratą dziecka. Śmierć dziecka dotyka nie tylko matkę czy oboje rodziców, ale również rodzeństwo zmarłego oraz dziadków, w mniejszym stopniu dalszą rodzinę. Wyjątkowość tej straty polega na jej niezgodności z naturalnym porządkiem rzeczy, pozwalającym zakładać, że to dzieci muszą zmierzyć się ze śmiercią swoich dziadków, a następnie rodziców, a nie odwrotnie. Żałoba po dziecku jest okresem zwiększonego zapotrzebowania na wsparcie społeczne, pomoc ze strony drugiego człowieka, osób bliskich, rodziny i przyjaciól, ale też nieznajomych, którzy mogą stawać się bliscy ze względu na wspólne doświadczenie.

Celem artykułu jest przedstawienie doświadczenia śmierci dziecka z perspektywy funkcjonowania rodziny jako całości, jak również jej poszczególnych członków (w pierwszej kolejności rodziców), ze szczególnym uwzględnieniem specyfiki żałoby po dziecku, kryzysowego charakteru doświadczenia oraz zapotrzebowania rodziny na wsparcie społeczne. Artykuł

* Dr Katarzyna Stankiewicz jest adiunktem w Zakładzie Teorii Wychowania w Instytucie Pedagogiki Uniwersytetu Gdańskiego. Adres: Instytut Pedagogiki UG, ul. Jana Bażyńskiego 4, 80-309 Gdańsk; e-mail: k.stankiewicz@ug.edu.pl.

${ }^{1}$ Por. Piotr Krakowiak, Strata, osierocenie i żałoba. Poradnik dla pomagajacych i dla osób w żałobie (Gdańsk: Via Medica, 2007), 70-78. 
ma charakter wprowadzenia do tematu - porusza szereg istotnych kwestii bez ich dogłębnej analizy, wskazując na wagę podjętego problemu oraz możliwe kierunki dalszych poszukiwań w tym obszarze.

Należy zaznaczyć, że dla przeżywania żałoby i zaistnienia sytuacji kryzysowej w rodzinie nie ma znaczenia wiek zmarłego dziecka ${ }^{2}$. Jednak ze względu na pewne różnice w przebiegu żałoby po osobie niepełnoletniej oraz dorosłej, w tym artykule swoją uwagę koncentruję przede wszystkim na rodzinach po stracie dziecka niepełnoletniego, począwszy od sytuacji poronienia, poprzez śmierć okołoporodową, po stratę dziecka w wieku niemowlęcym, przedszkolnym i szkolnym, abstrahując od przyczyn śmierci i jej charakteru (nagła, tragiczna, w wyniku choroby itp.).

Temat straty dziecka, szczególnie na gruncie polskim, nie został do tej pory dostatecznie zbadany, co przekłada się na braki w zakresie publikacji o charakterze poradnikowym dla osób pracujących z rodzinami znajdującymi się $\mathrm{w}$ tej sytuacji ${ }^{4}$. W większości opracowań problem straty dziecka pojawia się - w skromnym wymiarze - przy okazji rozważań odnoszących się do żałoby i kryzysu w wyniku śmierci kogoś bliskiego ${ }^{5}$, jednak żałoba po dziecku różni się intensywnością i czasem trwania od żałoby po śmierci innych bliskich osób ${ }^{6}$.

\section{1. Żałoba po dziecku a przemiany kulturowe}

Znaczenie straty dziecka dla rodziców w sposób metaforyczny ujmuje ks. Piotr Krakowiak: „Tracąc rodziców, tracimy naszą przeszłość. Wraz z utratą małżonka tracimy naszą teraźniejszość. Gdy tracimy dziecko, tra-

2 Pełnowymiarowa żałoba może mieć miejsce również na skutek poronienia. Patrz: Izabela Barton-Smoczyńska, „Adaptacja kobiet po śmierci dziecka poczętego”, w: Poronienie. Zrozumieć rodziców po stracie, red. Cyprian Klahs (Poznań: W drodze, 2010), 109-125.

${ }^{3}$ Por. Krakowiak, Strata, 70-78.

${ }^{4} \mathrm{Na}$ rynku dostępna jest przetłumaczona z języka angielskiego książka o charakterze poradnikowym: Catherine Sanders, Jak przeżyć stratę dziecka (Gdańsk: GWP, 2001).

${ }_{5}^{5}$ Patrz np.: Martin Herbert. Żałoba w rodzinie (Gdańsk: GWP, 2005); Krakowiak, Strata; Catherine Sanders, Powrót nadziei (Gdańsk: GWP, 1996); Wybrane zagadnienia interwencji kryzysowej. Poradnik dla pracowników socjalnych, wybór i oprac. Wanda Badura-Madej (Warszawa: Interart, 1996).

${ }^{6}$ Stanisława Tucholska, „Psychologiczna analiza procesu żałoby”, w: Psychologiczne aspekty doświadczania żałoby, red. Stefan Steuden, Stanisława Tucholska (Lublin: Wydawnictwo KUL, 2009), 12-15. 
cimy naszą przyszłość"ᄁ. Dziecko stanowi w pewnym sensie biologiczną cząstkę rodziców, co oznacza, że tracąc dziecko, po części umierają również sami rodzice ${ }^{8}$, a na pewno w sposób bezpośredni stykają się oni z fenomenem śmierci, co prowadzi do stawiania pytań o znaczeniu egzystencjalnym i przewartościowania wielu spraw ${ }^{9}$. Ból po stracie pogłębia świadomość roli przypisanej rodzicom jako tym, którzy dają życie i którzy mają to młode życie ochraniać, pielęgnować ${ }^{10}$. Emocjonalny wymiar straty oddaje określenie „osieroceni rodzice”, akcentujące ich bezradność i niemoc w obliczu śmierci dziecka.

Żałoba jest naturalną odpowiedzią na doświadczenie straty oraz jej konsekwencje. Możemy ją traktować jako formę przystosowania się „osieroconych" do życia bez osoby zmarłej. Podkreśla się, że ,żałoba nie jest chorobą, ale naturalną reakcją człowieka na krytyczne wydarzenie, jakim jest śmierć"11. Jest to proces wielowymiarowy, obejmujący sferę somatyczna, psychiczna, społeczną i behawioralną człowieka ${ }^{12}$. Specyfika żałoby sprawia, że osoba w tym stanie wymaga kompleksowej, wielowymiarowej pomocy. Żałoba ma określoną dynamikę. Najogólniej mówiąc, przebiega począwszy od fazy negacji faktu śmierci osoby bliskiej, poprzez fazę silnych emocji, rozpacz aż po ostatnią fazę integracji i pogodzenia się ze stratą. W przypadku straty dziecka w przebiegu żałoby może pojawić się szereg nieprawidłowości, które utrudniają, a także wydłużają proces adaptacji do życia bez osoby zmarłej, z najbardziej powszechnym problemem chroniczności żałoby ${ }^{13}$.

${ }^{7}$ Krakowiak, Strata, 74; por. Barton-Smoczyńska na temat przeżywania żałoby po poronieniu: „Odchodzą marzenia, nikną plany związane z przyszłością dziecka, z jej [matki] własnym macierzyństwem, z przyszłością rodziny”. Barton-Smoczyńska, „Adaptacja”, 109.

${ }^{8}$ Krakowiak, Strata, 75.

${ }^{9}$ Barbara Pilecka, Kryzys psychologiczny. Wybrane zagadnienia (Kraków: Wydawnictwo UJ, 2004), 190-195.

10 Józef Szymołon, „Wsparcie w procesie żałoby”, w: Psychologiczne aspekty doświadczania żałoby, red. Stefan Steuden, Stanisława Tucholska (Lublin: Wydawnictwo KUL, 2009), 245; por. Pilecka, Kryzys, 128-129.

${ }^{11}$ Wanda Badura-Madej, ,Problematyka utraty, osierocenia i żałoby w praktyce interwencji kryzysowej”, w: Wybrane zagadnienia interwencji kryzysowej. Poradnik dla pracowników socjalnych, wybór i oprac. Wanda Badura-Madej (Warszawa: Interart, 1996), 158.

12 Tucholska, „Psychologiczna analiza”, 21-27.

13 Tamże, 12-15; por. Mirona Ogryzko-Wiewiórowska, Rodzina i śmierć (Lublin: Wydawnictwo UMCS, 1994), 101. 
Przemiany kulturowe ograniczają publiczny wymiar przeżywania żałoby, wypierając doświadczenie śmierci poza bieg codziennego życia ${ }^{14}$. Wszechobecny kult sukcesu, zdrowia i młodości każe utratę dziecka traktować w kategoriach porażki, prowadzi do izolowania oraz stygmatyzacji cierpiących osób. Stygmatyzacja, która może dotykać również inne osoby w żałobie, wydaje się szczególnie silna w sytuacji utraty dziecka, ponieważ ta strata jest stosunkowo rzadka ${ }^{15}$. W kulturze współczesnej zanikają kultywowane dawniej zwyczaje żałobne. Żałoba wypierana jest ze sfery publicznej do przestrzeni osobistej. Jako czas przeżywania i uzewnętrzniania straty bywa najczęściej ograniczana do subtelnych komunikatów na poziomie ubioru.

Współcześnie mamy do czynienia z instytucjonalizacją śmierci. Rozbudowana sieć opieki szpitalnej i paliatywnej oraz działalność zakładów pogrzebowych sprawiają, że jesteśmy w pewnym sensie odizolowani od „umierania"16. Polscy pedagodzy i nauczyciele tematykę cierpienia, śmierci oraz przygotowania do niej podejmują raczej niechętnie, nie są do tego należycie przygotowani ${ }^{17}$. Dorosłe społeczeństwo jest bardziej skłonne do „chronienia” dzieci przed kontaktem ze śmiercią niż do budowania sytuacji o charakterze inicjacyjnym, które oswajałyby kolejne pokolenia ze świadomością nieuchronności śmierci i uczyły właściwego przeżywania żałoby ${ }^{18}$.

\section{Kryzys jednostki i rodziny w wyniku straty dziecka}

Żałoba dotyka poszczególnych członków rodziny, jak również rodziny jako całości, jako systemu. Nieobecność zmarłego dziecka przekłada się na

14 Patrz np. Zbyszko Melosik, „Kultura popularna jako czynnik socjalizacji”, w: Pedagogika. Podręcznik akademicki, t. 2, red. Zbigniew Kwieciński, Bogusław Śliwerski (Warszawa: PWN, 2009), 68-93.

15 Szymołon, „Wsparcie”, 245-246.

16 Por. Antonina Ostrowska, Śmierć w doświadczeniu jednostki i społeczeństwa (Warszawa: Wydawnictwo IFiS PAN, 1997), 30 i nast.

17 Przemysław P. Grzybowski, „Pedagogiczne cele i aspekty kształcenia tanatologicznego pedagogów i nauczycieli”, w: Jak rozmawiać z uczniami o końcu życia i wolontariacie hospicyjnym, red. Józef Binnebesel, Anna Janowicz, Piotr Krakowiak (Gdańsk: Via Medica, 2009), 7-8.

18 Anna Dodziuk, „O śmierci - z dziećmi tak jak z dorosłymi”, w: Jak rozmawiać z uczniami o końcu życia $i$ wolontariacie hospicyjnym, red. Józef Binnebesel, Anna Janowicz, Piotr Krakowiak (Gdańsk: Via Medica, 2009), 167. 
zmianę w zachowaniu rodziców i rodzeństwa, ale również w funkcjonowaniu rodziny. Jak zauważa Wanda Badura-Madej, w wyniku śmierci dziecka każdy z członków rodziny „traci nie tylko niepowtarzalny związek [z osobą zmarła] - i doświadcza indywidualnej straty, ale traci także dotychczasowy obraz rodziny"19. Śmierć dziecka stawia przed rodziną określone zadania, do których należą uporanie się ze stratą na poziomie osobistym, zmodyfikowanie struktury rodziny i dokonanie ponownego podziału ról oraz ponowne ustalenie relacji z otoczeniem ${ }^{20}$. Rola zmarłego dziecka może zostać „nieobsadzona”, jak również któreś z dzieci może ją przejąć, co wpłynie na jego dalszy rozwój oraz relacje z rodzicami ${ }^{21}$. Odejście dziecka, szczególnie w przypadku rodzin jedynaków, często prowadzi do zerwania więzi między rodzicami i rozpadu związku ${ }^{22}$.

Śmierć dziecka może być traktowana jako zdarzenie krytyczne ${ }^{23}$, które bardzo często prowadzi do kryzysu psychologicznego jednostek zaangażowanych emocjonalnie oraz kryzysu rodziny jako systemu. Za Heleną Sęk zdarzenie krytyczne możemy rozumieć jako wzajemne oddziaływanie na siebie jednostki i otoczenia, prowadzące do momentu zwrotnego, kiedy niezbędna jest zmiana. Zmiana ta dotyczy jednostki, otoczenia bądź też relacji między jednostką a otoczeniem ${ }^{24}$. Śmierć dziecka może być właśnie takim punktem zwrotnym w biografii rodziców i innych bliskich osób, który doprowadzi do przewartościowania wielu spraw i ponownego ułożenia relacji ze światem zewnętrznym ${ }^{25}$.

Zdarzenie, jakim jest śmierć dziecka, z reguły ma dla rodziców charakter traumatyczny, ponieważ znajduje się ,poza zakresem normalnych ludzkich

19 Badura-Madej, ,Problematyka utraty”, 164-165.

20 Tamże; por. Wiesława Okla, „Pomoc psychologiczna w sytuacji utraty”, w: Psychologiczne aspekty doświadczania żałoby, red. Stefan Steuden, Stanisława Tucholska (Lublin: Wydawnictwo KUL, 2009), 201-204.

${ }^{21}$ Badura-Madej, „Problematyka utraty”, 165.

22 Krakowiak, Strata, 76-77.

${ }^{23}$ Patrz np. Danuta Kubacka-Jasiecka, Interwencja kryzysowa. Pomoc w kryzysach psychologicznych (Warszawa: Wydawnictwa Akademickie i Profesjonalne, 2010). Więcej na temat straty dziecka jako zdarzenia krytycznego w: Katarzyna Stankiewicz, Alicja Zbierzchowska, „Dwa przypadki wydarzeń niepunktualnych w życiu kobiety - przedwczesne rozpoczęcie i zakończenie macierzyństwa. Analiza teoretyczna”, Niepetnosprawność 15 (2014): 114-115.

${ }^{24}$ Helena Sęk, ,Stres krytycznych wydarzeń życiowych”, w: Zdrowie - stres - zasoby, red. Helena Sęk, Tomasz Pasikowski (Poznań: Wydawnictwo Humaniora, 2001), 13-22.

${ }_{25}$ Stankiewicz, Zbierzchowska, „Dwa przypadki”, 111-121. 
przeżyć” i wydaje się ,istotnie zakłócające dla prawie wszystkich ludzi"26. Zdarzenie traumatyczne najczęściej wiąże się z konfrontacją jednostki ze śmiercią bliskiej osoby, jak również z poczuciem lęku i bezradności ${ }^{27}$, które to emocje często są udziałem rodziców umierających dzieci. Ze względu na nagły charakter zdarzenia traumatycznego możemy o nim mówić w przypadku niespodziewanej straty bądź w odniesieniu do otrzymania przez bliskich diagnozy o terminalnym charakterze choroby dziecka ${ }^{28}$. Wbrew potocznemu myśleniu o traumie w literaturze znajdziemy informacje o „korzyściach wynikających z doświadczeń traumatycznych", które mogą sprzyjać poszukiwaniom tożsamościowym, budowaniu nowej, trwalszej i zorientowanej prospołecznie hierarchii wartości, pozwalać na odnalezienie sensu życia oraz sprzyjać nawiązywaniu satysfakcjonujących relacji międzyludzkich ${ }^{29}$. Tego rodzaju zmiany na poziomie jednostki określa się mianem potraumatycznego wzrostu ${ }^{30}$.

Jednak nawet w przypadku prawidłowego przebiegu żałoby doświadczenie śmierci dziecka - właśnie ze względu na swoją traumatyczność może prowadzić do kryzysu. Kryzys, rozumiany tutaj jako „przejściowy stan nierównowagi wewnętrznej, wywołany przez krytyczne wydarzenie bądź wydarzenie życiowe, wymagające istotnych zmian i rozstrzygnięćc"31, miałby w tym przypadku charakter sytuacyjny (,traumatyczny”) ${ }^{32}$. Zaburzenie równowagi dotyczy zarówno jednostki, poszczególnych członków rodziny, jak również całego systemu ${ }^{33}$. Dla funkcjonowania rodziny wyjątkowo trudne wydaje się wystapienie w jednym czasie kryzysu na poziomie jednostki i rodziny, ponieważ osieroceni rodzice oczekują wsparcia w pierwszej ko-

${ }^{26}$ Cytaty z opisu zamieszczonego w Międzynarodowej Klasyfikacji Chorób przywołane za: Nina Ogińska-Bulik, Pozytywne skutki doświadczeń traumatycznych, czyli kiedy łzy zamieniaja się w perty (Warszawa: Difin, 2013), 12-13.

${ }^{27}$ Tamże; por. Grzegorz Sędek, „Jak ludzie radzą sobie z sytuacjami, na które nie ma rady?”, w: Zludzenia, które pozwalaja żyć, red. Mirosław Kofta, Teresa Szustrowa (Warszawa: PWN, 2001), 234 i nast.

${ }^{28}$ Por. tamże, 226.

29 Por. Izabela Barton-Smoczyńska, O dziecku, które odwróciło się na pięcie (Łomianki: NAF, 2006), 169-186; Viktor E. Frankl, Psychoterapia dla każdego (Warszawa: Pax, 1978).

30 Ogińska-Bulik, Pozytywne skutki, 246.

31 Wanda Badura-Madej, „Podstawowe pojęcia teorii kryzysu i interwencji kryzysowej”, w: Wybrane zagadnienia interwencji kryzysowej. Poradnik dla pracowników socjalnych, wybór i oprac. Wanda Badura-Madej (Warszawa: Interart, 1996), 16.

32 Tamże, 22-23.

33 Badura-Madej, „Problematyka utraty”, 164. 
lejności ze strony najbliższych, którzy w tym przypadku sami również tego wsparcia potrzebują ${ }^{34}$.

Przebieg żałoby w rodzinie zależy od kilku czynników, przede wszystkim od etapu rozwoju rodziny, struktury i komunikacji wewnątrzrodzinnej ${ }^{35}$. Możemy wyróżnić trzy źródła zasobów, z których korzysta rodzina w sytuacji kryzysu, odnoszące się do różnych poziomów: zasoby jednostki, rodziny jako systemu i społeczności. Na poziomie osobistym jako zasoby ułatwiające radzenie sobie z kryzysem można traktować między innymi: inteligencję, wiedzę, umiejętności, cechy osobowościowe oraz dotychczasowe doświadczenia. Na poziomie rodziny istotne są jej wysoka spójność i adaptacyjność, jak również umiejętności komunikacyjne jej członków. Trzeci poziom - społeczności - odnosi się do wsparcia społecznego ${ }^{36}$. Wspomniany wzrost potraumatyczny wydaje się możliwy nie tylko na poziomie jednostki, ale również w odniesieniu do rodziny jako systemu, na przykład w zakresie jakości więzi czy komunikacji między jej członkami, przy czym ważnym czynnikiem stymulującym ten wzrost jest właśnie wsparcie społeczne ${ }^{37}$.

\section{Wsparcie społeczne w sytuacji śmierci dziecka}

Żałoba to okres wyjątkowo silnego zapotrzebowania na wsparcie społeczne, które możemy rozumieć jako pomoc dostępną jednostce znajdującej się w sytuacji trudnej, mającą na celu mobilizowanie sił i zasobów jednostki tak, aby mogła sobie ona poradzić z problemem ${ }^{38}$. Żałoba to jednocześnie czas, kiedy pierwotna sieć wsparcia często nie sprawdza się ${ }^{39}$, przynajmniej

${ }^{34}$ Krakowiak, Strata, 75.

${ }^{35}$ Badura-Madej, „Problematyka utraty”, 165-166.

36 Stanisław Kawula, „Rodzina o skumulowanych czynnikach patogennych”, w: Pedagogika rodziny. Obszary i panorama problematyki, Stanisław Kawula, Józefa Bragiel, Andrzej W. Janke (Toruń: Wydawnictwo Adam Marszałek, 1997), 143; por. Elżbieta Leśniak, Agnieszka Dobrzyńska-Mesterhazy, „Rodziny w kryzysie: diagnoza i interwencja kryzysowa”, w: Wybrane zagadnienia interwencji kryzysowej. Poradnik dla pracowników socjalnych, wybór i oprac. Wanda Badura-Madej (Warszawa: Interart, 1996), 90-90; por. Izabela Krasiejko, Metodyka działania asystenta rodziny. Różne modele pracy terapeutycznej i socjalnej z rodzinq (Katowice: Wydawnictwo ,Śląsk”, 2012), 49-64.

37 Por. Sędek, „Jak ludzie”, 243.

38 Stanisław Kawula, ,Wsparcie społeczne - kluczowy wymiar pedagogiki społecznej”, Problemy Opiekuńczo-Wychowawcze 2 (1996): 6-7.

39 Por. Szymołon, „Wsparcie”, 245-247. 
jeśli chodzi o udzielanie wsparcia o charakterze emocjonalnym czy duchowym $^{40}$. Członkowie dalszej rodziny bywają wręcz obezwładnieni ogromem cierpienia, jaki jest udziałem rodziny po śmierci dziecka. Brakuje im wiedzy psychologicznej i doświadczenia, aby móc świadczyć pomoc w tej sytuacji. Bezradność rodziny często odbierana jest przez osieroconych jako obojętność, chłód emocjonalny ${ }^{41}$. Stygmatyzacja żałobników może również prowadzić do zerwania relacji ${ }^{42}$. Innym problemem jest banalizowanie, niedocenianie straty, a tym samym odmawianie osieroconym prawa do żałoby, co dość często zdarza się w sytuacji poronienia ${ }^{43}$.

Rodzina i przyjaciele, chcący pomóc cierpiącym po stracie rodzicom, czasami siegają po utarte zwroty, które nie przystają do doświadczeń żałobników i mogą prowadzić do nieprawidłowości w przebiegu żałoby. Możemy mówić w tym przypadku o „nietrafionym wsparciu”44, które przejawia się w takich popularnych formułach pocieszenia, jak: „czas leczy raczy”, „będziesz mieć jeszcze kolejne dziecko”, „musisz zapomnieć” czy też „dobrze, że umarło, chyba nie chcielibyście chować kaleki?!"45.

Analizując wsparcie społeczne kierowane do rodzin po stracie dziecka, należy zwrócić uwagę na „wsparcie odczuwane” przez osieroconych oraz adekwatność tego wsparcia, dostosowanie do ich potrzeb ${ }^{46}$. Ze względu na specyfikę straty rodzina i najbliżsi mogą nie być w stanie udzielić właściwego wsparcia na płaszczyźnie informacyjnej, emocjonalnej czy duchowej, dlatego też zasadne jest kierowanie osieroconych do grup wsparcia, gdzie będą oni mieli możliwość kontaktu z innymi osobami, które również doświadczyły śmierci dziecka ${ }^{47}$.

$\mathrm{W}$ zmaganiach z doświadczeniem straty istotna wydaje się perspektywa religijna, pozwalająca odnaleźć odpowiedzi na pytania o charakterze egzystencjalnym, których stawianie jest nieodłącznym elementem żałoby. Religia

${ }^{40} \mathrm{Na}$ temat wymiarów wsparcia społecznego patrz Stanisław Kawula, „Wsparcie społeczne", w: Elementarne pojęcia pedagogiki społecznej i pracy socjalnej, red. Danuta Lalak, Tadeusza Pilch (Warszawa: „Żak”, 1999), 340.

${ }^{41}$ Szymołon, „Wsparcie”, 245-246.

42 Tamże.

43 Barton-Smoczyńska, „Adaptacja”, 110.

${ }^{44}$ Katarzyna Nowak, „Czynniki utrudniające przebieg procesu żałoby”, w: Psychologiczne aspekty doświadczania żałoby, red. Stefan Steuden, Stanisława Tucholska (Lublin: Wydawnictwo KUL, 2009), 46.

45 Por. tamże.

46 Szymołon, „Wsparcie”, 242-243; por. Kubacka-Jasiecka, Interwencja, 177-179.

47 Badura-Madej, ,Problematyka utraty”, 171-172. 
wyjaśnia sens życia i śmierci, przełamując jednocześnie poczucie nieodwracalności tej ostatniej. Oferuje szereg rytuałów, pomagających przepracować stratę $^{48}$.

\section{Zakończenie}

Rodzina w sytuacji śmierci dziecka bez wątpienia potrzebuje wielowymiarowego wsparcia społecznego. Otoczenie nie zawsze jest przygotowane do udzielenia tego typu wsparcia. Adekwatną i wielowymiarową pomoc można otrzymać w grupach wsparcia, szczególnie tych uwzględniających perspektywę religijną w podejściu do śmierci oraz cierpienia. Wydaje się jednak, że jakość pierwotnej sieci wsparcia można podnosić poprzez odpowiednie działania edukacyjne i kampanie społeczne, tworzone chociażby na wzór powszechnie znanej ogólnopolskiej kampanii „Hospicjum to też Życie”49.

Mimo że analiza materiału empirycznego nie była celem tego artykułu, na zakończenie warto oddać głos samym osieroconym ${ }^{50}$, którzy w sposób przejmujący wyrażają ogrom dotykającego ich cierpienia, opisują swoje problemy w kontaktach z otoczeniem oraz znaczenie grupy wsparcia.

Emocje po śmierci dziecka?

Kiedy umarł mój syn, miałam wrażenie, że świat się kończy. [...] Zaczęłam balansować na pograniczu życia i śmierci./Wszystko straciło sens./Miałam wrażenie, że zaraz się obudzę./Co dzień pytam: dlaczego?

Reakcje otoczenia?

Niektórzy boją się, sprawiają wrażenie, jakby mieli zarazić się nieszczęściem./ Nikt nie porozmawia, nie powie dobrego słowa.

Znaczenie grupy wsparcia?

Dzięki ludziom, którzy byli zawsze przy mnie i których poznałam - osieroconym rodzicom - wybrałam życie./Poznałam też ludzi, którzy są w podobnej sy-

48 Andrzej Sereda, „Poradnictwo pastoralne w sytuacji utraty osób bliskich”, w: Psychologiczne aspekty doświadczania żałoby, red. Stefan Steuden, Stanisława Tucholska (Lublin: Wydawnictwo KUL, 2009), 233-240.

49 Patrz www.hospicja.pl/akcje/article/10749/10750.html [dostęp: 21.09.2012].

${ }^{50}$ Wszystkie zamieszczone dalej cytaty pochodzą ze strony: www.stratadziecka.pl [dostęp: 21.09.2012]. Są to wypowiedzi rodziców współtworzących Trójmiejską Wspólnotę po Stracie Dziecka. 
tuacji jak my, którzy są rodzicami aniołów, i ta świadomość, że oni są i zawsze są chętni, żeby porozmawiać, ratuje mnie. To takie ważne móc podzielić się z kimś swoim bólem, móc wyrzucić to z siebie i płakać łzami, które oczyszczą zranione serce.

Osieroceni mają również swoje dość proste recepty na „adekwatne wsparcie społeczne". Na pytanie, jak pomóc, odpowiadają:

Proszę wszystkich, którzy w swojej rodzinie lub wśród znajomych zetkną się $\mathrm{z}$ taką sytuacją [śmiercią dziecka], nie ignorujcie naszego cierpienia, nie chowajcie się pod płaszczem milczenia. Czasami wystarczy tak mało: dobre słowo (współczuję ci, tak mi przykro), wysłuchanie czy chociażby wspólne milczenie. Nie mówcie tych wszystkich sloganów, które strasznie bolą (nic się nie stało, nie ty pierwsza nie ostatnia, Bóg tak chciał...), tylko po prostu bądźcie ${ }^{51}$.

\section{A Family and a Death of a Child. Bereavement and Social Support (Summary)}

The paper aims at presenting a child's death as a critical incident both for a family viewed as a system and for its members, and examines the potential challenges and dangers faced when a social support is given in such circumstances. The author addresses the issue of bereavement after a child's death as a particular type of mourning, describing the dynamics of the process and factors conditioning its proper course. A child's death is seen as a cause of crisis. The author presents individual and family resources, which enable parents to cope with this particular experience and emphasises the need of the multidimensional social support that is necessary for parents to survive such an ordeal. At the same time the potential obstacles are defined when such as support is given, which mainly refers to its inadequacy. Participation in an external support group is presented by the author as an effective alternative to support given by the relatives of those affected by a child's death.

Key words: family; child's death; crisis; bereavement; social support.

${ }^{51}$ Por. Lista życzeń osieroconych rodziców na stronie ogólnopolskiego serwisu dla rodziców osieroconych i rodziców po stracie „Dlaczego”: www.dlaczego.org.pl [dostęp: 21.09.2012]. 


\section{Rodzina wobec śmierci dziecka. Żałoba, kryzys, wsparcie społeczne (Streszczenie)}

Celem artykułu jest przedstawienie śmierci dziecka jako sytuacji kryzysowej dla rodziny jako systemu i jej członków, jak również analiza potencjalnych wyzwań czy zagrożeń związanych ze wsparciem społecznym w tych okolicznościach. Autorka odnosi się do kwestii żałoby po śmierci dziecka jako szczególnego rodzaju żałoby, opisując dynamikę procesu oraz czynniki warunkujące jego prawidłowy przebieg. Śmierć dziecka jest postrzegana jako przyczyna kryzysu. Autorka przedstawia zasoby jednostki i rodziny, które umożliwiają radzenie sobie z tym szczególnym doświadczeniem i podkreśla potrzebę wielowymiarowego wsparcia społecznego, które jest konieczne, aby przetrwać taką gehennę. Jednocześnie określane są potencjalne przeszkody związane z udzielaniem takiego rodzaju wsparcia, których przyczyną jest głównie ich nieadekwatność. Uczestnictwo w zewnętrznej grupie wsparcia zostało przedstawione przez autorkę jako alternatywa dla wsparcia ze strony krewnych dotkniętych śmiercią dziecka.

Słowa kluczowe: rodzina; śmierć dziecka; strata dziecka; kryzys; żałoba; wsparcie społeczne.

\section{Bibliografia}

Badura-Madej, Wanda. „Podstawowe pojęcia teorii kryzysu i interwencji kryzysowej”. W: Wybrane zagadnienia interwencji kryzysowej. Poradnik dla pracowników socjalnych, wybór i oprac. Wanda Badura-Madej, 15-31. Warszawa: Interart, 1996.

Badura-Madej, Wanda. „Problematyka utraty, osierocenia i żałoby w praktyce interwencji kryzysowej”. W: Wybrane zagadnienia interwencji kryzysowej. Poradnik dla pracowników socjalnych, wybór i oprac. Wanda Badura-Madej, 157-174. Warszawa: Interart, 1996.

Barton-Smoczyńska, Izabela. „Adaptacja kobiet po śmierci dziecka poczętego”. W: Poronienie. Zrozumieć rodziców po stracie, red. Cyprian Klahs, 109-125. Poznań: W drodze, 2010.

Barton-Smoczyńska, Izabela. O dziecku, które odwróciło się na pięcie. Łomianki: NAF, 2006. 
Dodziuk, Anna. „O śmierci - z dziećmi tak jak z dorosłymi”. W: Jak rozmawiać z uczniami o końcu życia $i$ wolontariacie hospicyjnym, red. Józef Binnebesel, Anna Janowicz, Piotr Krakowiak, 167-180. Gdańsk: Via Medica, 2009.

Frankl, Viktor E. Psychoterapia dla każdego. Warszawa: Pax, 1978.

Grzybowski, Przemysław P. „Pedagogiczne cele i aspekty kształcenia tanatologicznego pedagogów i nauczycieli”. W: Jak rozmawiać z uczniami o końcu życia $i$ wolontariacie hospicyjnym, red. Józef Binnebesel, Anna Janowicz, Piotr Krakowiak, 7-19. Gdańsk: Via Medica, 2009.

Herbert, Martin. Żałoba w rodzinie, przeł. Monika Gajdzińska. Gdańsk: GWP, 2005. Kawula, Stanisław. „Rodzina o skumulowanych czynnikach patogennych”. W: Pedagogika rodziny. Obszary i panorama problematyki, Stanisław Kawula, Józefa Bragiel, Andrzej W. Janke, 114-152. Toruń: Wydawnictwo Adam Marszałek, 1997.

Kawula, Stanisław. „Wsparcie społeczne - kluczowy wymiar pedagogiki społecznej". Problemy Opiekuńczo-Wychowawcze 2 (1996): 6-7.

Kawula, Stanisław. „Wsparcie społeczne”. W: Elementarne pojęcia pedagogiki spotecznej i pracy socjalnej, red. Danuta Lalak, Tadeusza Pilch, 338-341. Warszawa: „Żak”, 1999.

Krakowiak, Piotr. Strata, osierocenie $i$ żałoba. Poradnik dla pomagajacych $i$ dla osób w żałobie. Gdańsk: Via Medica, 2007.

Krasiejko, Izabela. Metodyka działania asystenta rodziny. Różne modele pracy terapeutycznej i socjalnej z rodzinq. Katowice: Wydawnictwo „Śląsk”, 2012.

Kubacka-Jasiecka, Danuta. Interwencja kryzysowa. Pomoc w kryzysach psychologicznych. Warszawa: Wydawnictwa Akademickie i Profesjonalne, 2010.

Leśniak, Elżbieta, Agnieszka Dobrzyńska-Mesterhazy. „Rodziny w kryzysie: diagnoza i interwencja kryzysowa". W: Wybrane zagadnienia interwencji kryzysowej. Poradnik dla pracowników socjalnych, wybór i oprac. Wanda BaduraMadej, 83-101. Warszawa: Interart, 1996.

Melosik, Zbyszko. „Kultura popularna jako czynnik socjalizacji”. W: Pedagogika. Podręcznik akademicki, red. Zbigniew Kwieciński, Bogusław Śliwierski, t. 2, 68-93. Warszawa: PWN, 2009.

Nowak, Barbara M. Rodzina w kryzysie. Studium resocjalizacyjne. Warszawa: PWN, 2012.

Nowak, Katarzyna. „Czynniki utrudniające przebieg procesu żałoby”. W: Psychologiczne aspekty doświadczania żałoby, red. Stefan Steuden, Stanisława Tucholska, 35-49. Lublin: Wydawnictwo KUL, 2009.

Ogińska-Bulik, Nina. Pozytywne skutki doświadczeń traumatycznych, czyli kiedy tzy zamieniaja się w perty. Warszawa: Difin, 2013. 
Ogryzko-Wiewiórowska, Mirona. Rodzina i śmierć. Lublin: Wydawnictwo UMCS, 1994.

Okla, Wiesława. „Pomoc psychologiczna w sytuacji utraty”. W: Psychologiczne aspekty doświadczania żałoby, red. Stefan Steuden, Stanisława Tucholska, 199-205. Lublin: Wydawnictwo KUL, 2009.

Ostrowska, Antonina. Śmierć w doświadczeniu jednostki i społeczeństwa. Warszawa: Wydawnictwo IFiS PAN, 1997.

Pilecka, Barbara. Kryzys psychologiczny. Wybrane zagadnienia. Kraków: Wydawnictwo UJ, 2004.

Sanders, Catherine. Jak przeżyć stratę dziecka, przeł. Elżbieta Knoll. Gdańsk: GWP, 2001.

Sanders, Catherine. Powrót nadziei, przeł. Elżbieta Knoll. Gdańsk: GWP, 1996.

Sereda, Andrzej. „Poradnictwo pastoralne w sytuacji utraty osób bliskich”. W: Psychologiczne aspekty doświadczania żałoby, red. Stefan Steuden, Stanisława Tucholska, 233-240. Lublin: Wydawnictwo KUL, 2009.

Sędek, Grzegorz. „Jak ludzie radzą sobie z sytuacjami, na które nie ma rady?”. W: Złudzenia, które pozwalaja żyć, red. Mirosław Kofta, Teresa Szustrowa, 226248. Warszawa: PWN, 2001.

Sęk, Helena. „Stres krytycznych wydarzeń życiowych”. W: Zdrowie - stres - zasoby, red. Helena Sęk, Tomasz Pasikowski, 13-22. Poznań: Wydawnictwo Humaniora, 2001.

Stankiewicz, Katarzyna, Alicja Zbierzchowska. „Dwa przypadki wydarzeń niepunktualnych w życiu kobiety - przedwczesne rozpoczęcie i zakończenie macierzyństwa. Analiza teoretyczna”. Niepetnosprawność 15 (2014): 111-121.

Szymołon, Józef. „Wsparcie w procesie żałoby”. W: Psychologiczne aspekty doświadczania żałoby, red. Stefan Steuden, Stanisława Tucholska, 241-251. Lublin: Wydawnictwo KUL, 2009.

Tucholska, Stanisława. „Psychologiczna analiza procesu żałoby”. W: Psychologiczne aspekty doświadczania żałoby, red. Stefan Steuden, Stanisława Tucholska, 11-33. Lublin: Wydawnictwo KUL, 2009.

Wybrane zagadnienia interwencji kryzysowej. Poradnik dla pracowników socjalnych, wybór i oprac. Wanda Badura-Madej. Warszawa: Interart, 1996. 
